\title{
Current trends and macroeconomic effects of fiscal space functioning of Ukraine
}

\author{
Halyna Vasylevska ${ }^{1, *}$ \\ ${ }^{1}$ Ternopil National Economic University, 5A Lvivskaya St., 46020 Ternopil, Ukraine
}

\begin{abstract}
Modern features of fiscal space functioning of Ukraine are investigated in this article, the conditions and trends of its formation in the context of global social and economic transformations are determined. The theoretical principles of forming the fiscal space of the state are considered. The author gives explanations of definitions: fiscal environment and fiscal space. The components of the fiscal space are outlined and the course of their interaction within the defined fiscal environment as the basic component of the mechanism of formation of mutual relations for the reproduction of the efficiency and effective functioning of the assimilative formations of the fiscal space is determined. The monitoring of the macroeconomic environment of the formation of the fiscal space in Ukraine has been monitored. Ukraine's place in international ratings has been shown and a number of key indicators has been analyzed, on the basis of which the main reasons for the exacerbation of permanent economic and social crises were clarified, as well as the main guidelines for overcoming them.
\end{abstract}

\section{Introduction}

Modern transformations of the world economic system have a significant impact on local economic processes that take place on the basis of intensive globalization. Ukraine, a country that is territorially within the European continent, today is a source of political, social and economic instability, which negatively affects its foreign and domestic economic policy. By forming an appropriate resource base, subject to its rational use and civilized legal relations, the government could create and implement effective state regulation instruments, as well as influence on relevant processes in society and provide optimal conditions for its development and self-improvement. Instead, by producing a series of ineffective economic reforms, the state only deepens the crisis, which is exacerbated by the foreign aggression of the Russian Federation in the east of Ukraine, the annexation of Crimea, an increase in the rates of labor migration, significant indicators of inflation and inappropriate tax burden. Thus, effective formation of the fiscal space of the state and its prospect in the context of optimal use require detailed study, analysis and substantiation of many economic aspects.

Scientists-economists have devoted a great deal of works to analysis of theoretical and practical issues of the formation and development of the fiscal space, in combination with

\footnotetext{
* Corresponding author: vasylevskah@gmail.com
} 
the subjective experience of the functioning and evolution of national economies, but the challenges of the modern world confirm the importance of their careful studying. A considerable contribution to development of theories and methodological base of fiscal space functioning was done by contemporaries, foreign specialists: N. Alexsandr, M. Vahoeven, A. Ghosh, P. Heller, K. Dobrowolski， B. Jeliński,J. Kim, P. Kulawczuk, M. Qureshi, E. Letouze, E. Mendoza, S. Owsiak, D. Ostry, A. Rajaram, R. Roy, C. Tautz, A. Heuty, Sh. Sharma. At the same time, our attention was drawn to the works of domestic scientists who thoroughly studied certain aspects of fiscal space in the international and local dimensions: V. Andrushchenko, O. Vasylyk, V. Heiets, V. Demianyshyn, T. Yefymenko, Ya. Zhalilo, O. Kyrylenko, T. Kizima, N. Kravchuk, A. Krysovatyy, I. Lunina, Z. Lutsyshyn, M. Melnyk, O. Moldovan, A. Sokolovska, V. Sutormina, S. Yurii. However, the current transformations of the global economy give rise to new demands on the part of the state and society, which certainly leads to imbalance of the fiscal space. Therefore, the development of this problem requires a more thorough study.

Thus, the purpose of writing the article is to find and identify effective ways to ensure the stable development of a socially oriented market economy in Ukraine, and thus to ensure its economic growth, which, in its turn, requires an exhaustive study of the conditions of functioning and trends in the development of the fiscal space of the state.

\section{Theoretical principles of fiscal space formation}

The world economy as a holistic structure of national economic systems interconnected by fiscal relations, is in a constant dynamic movement and absorbs various exogenous and endogenous factors of the proper environment, the presence of which accelerates or inhibits the development of competitive advantages of a state and forms the corresponding asymmetries of its economic evolution. At the same time, the state ability to adequately withstand the pressure of rivalry in accessible conditions is determined, first of all, by the level of its competencies in the political, economic, social and financial spheres. It is precisely on the basis of the interaction of these parameters of social development that the fractal basis of the formation of the fiscal space, defined by us as an environment, forms an integral base component of the mechanism of the formation of mutual relations for the reproduction of the effectiveness and effective functioning of other, assimilative formations: institutional, financial, tax environments, etc. At the same time, the fiscal environment serves as the basis for building the same domain of the state and is defined as a system of logical combinations and circumstances that arise in the conditions of fiscal policy implementation within the framework of organizational and legal relations of subjects of taxation.

In the process of studying the conceptual foundations of the formation, functioning and development of the fiscal space of Ukraine, the problem of a thorough study and analysis of its internal content and the external environment appears, so without detailed diagnosis of macroeconomic indicators and the definition of existing trends it is difficult to focus on the priority inquiries of its transformation and improvement.

First of all, it should be noted that fiscal space is a combination of economic, political, financial and social relations that arise between the state and society in securing their own interests in the process of implementing fiscal policy with a view to distributing and redistributing the gross domestic product, balancing budgetary resources, as well as the formation of stable sources of funding for the main activities of the state, determined by the respective goals and objectives. Therefore, to ensure its optimal functioning and development, an important aspect is the study of interdependent spheres that determine the relevant conditions and trends in its formation. 
Relying on modern studies of fiscal space: [1] it is worth to emphasize four-component structure and full coverage of the combined units and we note that its formation takes place in four previously named, mutually interconnected sectors of the functioning of society (Fig. 1), namely: political, social, economic and financial. All of them are equally dependent on each other, they cannot function autonomously and outside the fiscal space of the state.

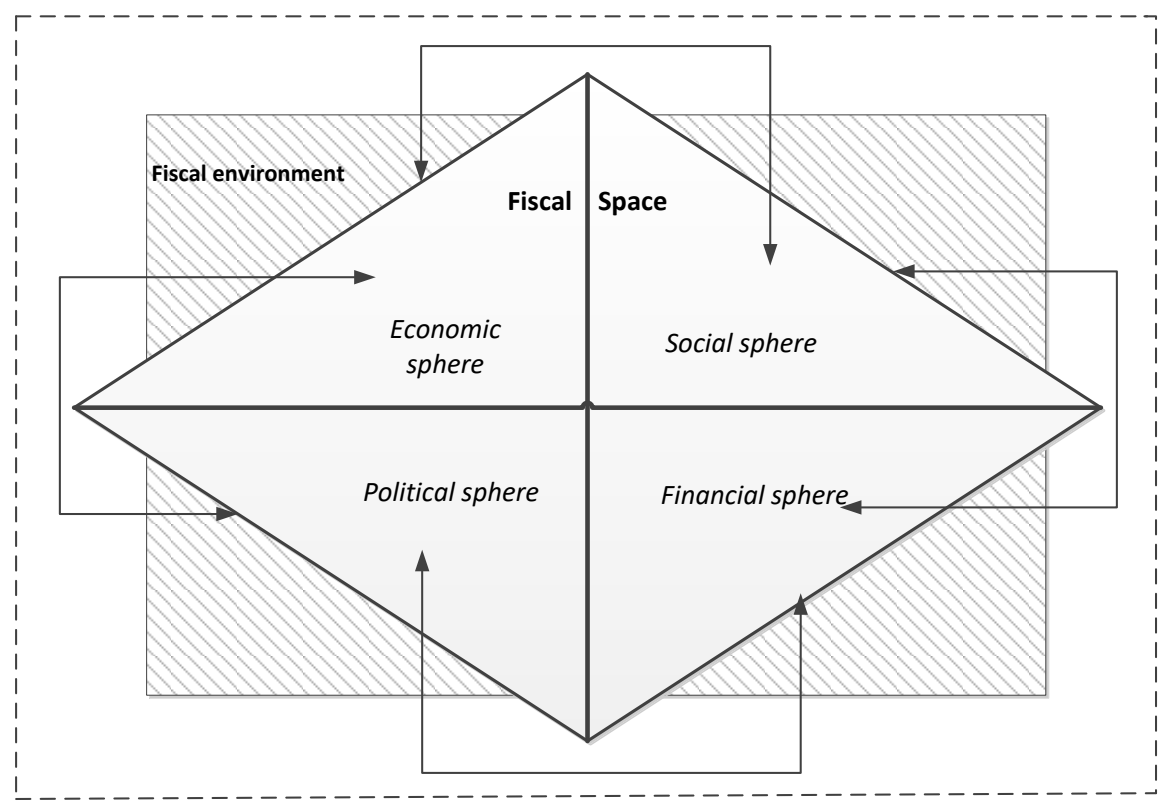

Fig. 1. Components of the fiscal space of the state and their interconnection.

At the same time, the fiscal environment is formally defined as the basis for building a fiscal space, established by the state in the form of relevant norms and rules, as well as certain conditions for its formation and development (see Fig. 1.). The political component, through the current legislation, acts on the processes of functioning and transformation of the national economic system, which in turn influences the social level of development of society, all of which, in the final analysis, is directly related to the structural separation of fiscal instruments, which are based on the financial ability of the state to fulfill its direct functions.

\section{Monitoring of the macroeconomic environment in the context of fiscal space formation in Ukraine}

Modern tendencies of divergent economic development outline the corresponding properties of the fiscal space and influence the functioning and interaction of its components. Instead, the domestic economic policy of Ukraine forms its own characteristic features in a competitive global environment (Table 1.) [2]. 
Table 1. Dynamics of Ukraine position in key international ratings in 2015-2017.

\begin{tabular}{|c|c|c|c|c|c|c|}
\hline Ranking list & Year & $\begin{array}{c}\text { Place of } \\
\text { Ukraine } \\
\text { /Total } \\
\text { number }\end{array}$ & Dynamics & Year & $\begin{array}{c}\text { Place of } \\
\text { Ukraine } \\
\text { /Total } \\
\text { number }\end{array}$ & Dynamics \\
\hline The Global Innovation Index & 2015 & $64 / 141$ & -1 & 2017 & $50 / 127$ & 6 \\
\hline Global Terrorism index & 2015 & $12 / 124$ & 39 & 2017 & $17 / 134$ & -6 \\
\hline Health and primary education & 2015 & $45 / 140$ & No change & 2017 & $53 / 137$ & 1 \\
\hline Rule of law index & 2015 & $70 / 102$ & 14 & 2017 & $77 / 113$ & 1 \\
\hline $\begin{array}{l}\text { The Global Gender Gap } \\
\text { Index }\end{array}$ & 2015 & $67 / 145$ & -11 & 2017 & $61 / 144$ & 8 \\
\hline Index of Globalization & 2015 & $42 / 207$ & 2 & 2016 & $45 / 207$ & -3 \\
\hline The Global Wealth Report & 2015 & $83 / 160$ & -4 & 2016 & $98 / 173$ & -12 \\
\hline Index of Economy Freedom & 2015 & $162 / 188$ & No change & 2017 & $150 / 180$ & 16 \\
\hline Bloomberg Innovation Index & 2015 & $41 / 50$ & -8 & 2017 & $46 / 50$ & -4 \\
\hline $\begin{array}{l}\text { The Global Competitives } \\
\text { Index }\end{array}$ & 2015 & $79 / 144$ & -3 & 2017 & $81 / 137$ & 4 \\
\hline Higher Education & 2015 & $34 / 144$ & 6 & 2017 & $35 / 137$ & -2 \\
\hline Easy of Doing Business & 2015 & $83 / 189$ & 13 & 2017 & $76 / 190$ & 4 \\
\hline Human Development Index & 2015 & $84 / 188$ & -3 & 2016 & $84 / 187$ & No change \\
\hline Fragile States Index & 2015 & $84 / 178$ & 29 & 2017 & $90 / 178$ & -5 \\
\hline $\begin{array}{l}\text { Global Firepower Military } \\
\text { Raks }\end{array}$ & 2015 & $25 / 126$ & -5 & 2017 & $30 / 133$ & No change \\
\hline The legatum prosperity index & 2015 & $107 / 142$ & -6 & 2017 & $112 / 149$ & No change \\
\hline Social Progress Index & 2015 & $62 / 133$ & No change & 2017 & $64 / 128$ & -1 \\
\hline Corruption perception Index & 2015 & $130 / 168$ & 12 & 2017 & $130 / 170$ & 1 \\
\hline World Happines Report & 2015 & $111 / 158$ & No data & 2017 & $138 / 156$ & -15 \\
\hline Paying taxes ranking & 2015 & $107 / 189$ & 1 & 2017 & $43 / 189$ & 41 \\
\hline $\begin{array}{l}\text { World Competitiveness } \\
\text { Yearbook }\end{array}$ & 2015 & $60 / 61$ & -11 & 2017 & $60 / 63$ & -1 \\
\hline World Press Freedom Index & 2015 & $129 / 180$ & -2 & 2017 & $102 / 180$ & 5 \\
\hline $\begin{array}{l}\text { E\&Y Fraud Surveys: } \\
\text { Corruption perception* }\end{array}$ & 2015 & $2 / 57$ & 5 & 2016 & $1 / 41$ & 1 \\
\hline
\end{tabular}

* - This abbreviation stands for Corruption Perception Index, an annual ranking of countries across the world first composed by Transparency International in 1995. The rating reflects the perception of corruption from 100 (no corruption) to 0 (strong corruption). The countries are ranked by the level of corruption based on a combination of independent surveys and assessments of the corruption level. Prominent international finance and advocacy experts participate in this research, including those from the World Bank, Freedom House, World Economic Forum, Asian and African development banks etc. [3].

Assessing the prospects of Ukraine for the coming years, it is clear that there is no need to expect any positive changes. According to the results of 2018 , the index of economic freedom in Ukraine increase to 3.8 points, compared to the previous, 2017, which is 51.9 points and provide 150 place in the overall ranking of 180 researched countries (Table 2.) [4]. 
Table 2. Index of economic freedom in selected countries of the world in 2018.

\begin{tabular}{|c|c|c|c|c|c|c|c|c|c|c|}
\hline 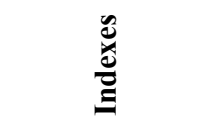 & 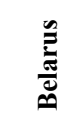 & 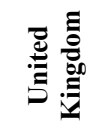 & 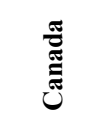 & 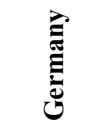 & 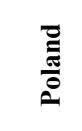 & 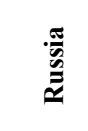 & 总 & 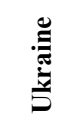 & 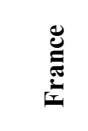 & 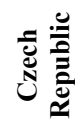 \\
\hline 1 & 2 & 3 & 4 & 5 & 6 & 7 & 8 & 9 & 10 & 11 \\
\hline World Ranking & 108 & 8 & 9 & 25 & 45 & 107 & 18 & 150 & 71 & 24 \\
\hline Region Rank & 42 & 4 & 1 & 14 & 21 & 41 & 2 & 44 & 34 & 13 \\
\hline 2018 Score & 58,1 & 78,0 & 77,7 & 74,2 & 68,5 & 58,2 & 75,7 & 51,9 & 63,9 & 74,2 \\
\hline $\begin{array}{l}\text { Property } \\
\text { Rights }\end{array}$ & 57,3 & 92,2 & 87,5 & 81,0 & 61,8 & 48,7 & 79,3 & 41,0 & 84,0 & 73,0 \\
\hline $\begin{array}{l}\text { Government } \\
\text { Integrity }\end{array}$ & 42,0 & 79,0 & 78,3 & 75,3 & 50,9 & 38,1 & 71,9 & 29,0 & 65,1 & 51,1 \\
\hline Tax Burden & 89,8 & 63,2 & 76,7 & 61,3 & 75,9 & 85,8 & 65,1 & 80,2 & 47,3 & 82,9 \\
\hline Gov't spending & 47,9 & 44,4 & 52,3 & 41,3 & 47,8 & 85,8 & 65,1 & 80,2 & 2,7 & 48,6 \\
\hline Fiscal Health & 75,4 & 53,5 & 81,2 & 90,8 & 81,5 & 87,7 & 54,8 & 75,9 & 60,8 & 96,2 \\
\hline $\begin{array}{l}\text { Business } \\
\text { Freedom }\end{array}$ & 74,1 & 91,1 & 81,8 & 86,1 & 67,2 & 77,0 & 82,7 & 62,7 & 80,2 & 72,5 \\
\hline $\begin{array}{l}\text { Labor } \\
\text { Freedom }\end{array}$ & 73,1 & 74,4 & 71,3 & 53,3 & 63,9 & 52,0 & 91,4 & 52,8 & 45,0 & 76,8 \\
\hline $\begin{array}{l}\text { Monetary } \\
\text { Freedom }\end{array}$ & 62,3 & 85,2 & 77,5 & 86,2 & 85,0 & 60,8 & 78,6 & 60,1 & 81,6 & 85,2 \\
\hline Trade Freedom & 81,4 & 86,9 & 88,1 & 86,9 & 86,9 & 79,4 & 86,7 & 81,1 & 81,9 & 86,9 \\
\hline $\begin{array}{l}\text { Investment } \\
\text { Freedom }\end{array}$ & 30 & 90 & 80 & 80 & 75 & 30 & 85 & 35 & 60 & 80 \\
\hline $\begin{array}{l}\text { Financial } \\
\text { Freedom }\end{array}$ & 10 & 80 & 80 & 70 & 70 & 30 & 80 & 30 & 40 & 80 \\
\hline Tariff rate, $\%$ & 1,8 & 1,6 & 1,0 & 1,6 & 1,6 & 2,8 & 1,6 & 1,9 & 1,6 & 1,6 \\
\hline $\begin{array}{l}\text { Income Tax } \\
\text { Rate, \% }\end{array}$ & 13 & 45 & 33 & 47,5 & 32 & 13 & 39,6 & 20 & 45 & 15 \\
\hline $\begin{array}{l}\text { Corporate Tax } \\
\text { Rate, } \%\end{array}$ & 18 & 20 & 15 & 15,8 & 19 & 20 & 35 & 18 & 34,3 & 19 \\
\hline $\begin{array}{l}\text { Tax burden \% } \\
\text { of GDP }\end{array}$ & 23,0 & 32,5 & 31,9 & 36,9 & 32,1 & 29,2 & 26,4 & 35,5 & 45,5 & 33,5 \\
\hline $\begin{array}{l}\text { GDP, } \\
\text { billion. USD }\end{array}$ & 171,0 & 2785,6 & 1662,4 & 3980,3 & 1054,1 & 3799,7 & 18569,1 & 353,0 & 2733,7 & 350,7 \\
\hline $\begin{array}{l}\text { GDP Grows } \\
\text { Rate, \% }\end{array}$ & $-3,9$ & 2,2 & 1,2 & 1,5 & 3,6 & $-3,7$ & 2,1 & $-9,9$ & 1,1 & 4,2 \\
\hline $\begin{array}{l}\text { Public Debt (\% } \\
\text { of GDP) }\end{array}$ & 52,3 & 89,2 & 92,3 & 67,6 & 54,2 & 17,9 & 107,4 & 81,2 & 96,6 & 37,7 \\
\hline
\end{tabular}

This fact became the result of a slowdown in the development of the oligarchic economy since 2004. At the same time, a number of unresolved issues: the external aggression of the Russian Federation on the East of Ukraine, the annexation of Crimea, an increase in the rate of labor migration, significant indicators of inflation and significant tax burden - negatively affect the overall image of the state. In addition, the problems associated with the functioning of small and medium business remained unresolved. It should be noted that during the whole period of formation of the rating of economic freedom, since 1995, the value of Ukraine did not exceed the indicator of 56 points out of 100 possible [5].

At the same time, the tax burden (80.2), which is $35.5 \%$, as a percentage of GDP, and the fiscal health index fixed at 75.9 points against the background of total corruption, low productivity and low purchasing power of citizens are not signs of the effectiveness of the government's previously implemented reforms.

According to experts of the International Monetary Fund, the shadow economy in Ukraine exceeds $40 \%$ of GDP, which is about 53 billion US dollars, which is the resources 
that taxes do not come to the budget. The total tax burden in Ukraine is more than $50 \%$ of profit/income. Thus, in the conditions of complete nationalization of the national economy, the state could additionally receive about $\$ 28$ billion annually [6].

Overall, 8 out of 12 indicators of economic freedom have improved, with a particular emphasis on improving financial freedom and investment freedom. However, there was no special activity of investors. The risks of loss of equity in an unstable political and economic situation, as well as corruption of the judicial system, significantly restrain investment activity in the state. In addition, Ukraine in the definitive rating of economic

Table 3. Dynamics of total population and adult population in the selected countries of the world from 2000 to 2016, thousand people.

\begin{tabular}{|c|c|c|c|c|c|c|c|c|c|c|}
\hline \multicolumn{2}{|c|}{ Indexes } & 2000 & 2005 & 2010 & 2011 & 2012 & 2013 & 2014 & 2015 & 2016 \\
\hline 1 & 2 & 3 & 4 & 5 & 6 & 7 & 8 & 9 & 10 & 11 \\
\hline \multirow{2}{*}{ 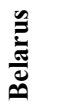 } & I & 10,054 & 9,816 & 9,588 & 9,542 & 9,496 & 9,449 & 9,402 & 9,379 & 9,331 \\
\hline & II & 7,357 & 7,475 & 7,537 & 7,572 & 7,561 & 7,543 & 7,519 & 7,504 & 7,473 \\
\hline \multirow{2}{*}{ 总 } & I & 58,907 & 60,251 & 61,899 & 62,231 & 62,559 & 62,884 & 63,207 & 63,368 & 63,687 \\
\hline & II & 44,072 & 45,464 & 47,188 & 47,538 & 47,883 & 48,220 & 48,543 & 48,696 & 48,993 \\
\hline \multirow{2}{*}{ 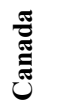 } & I & 30,687 & 32,307 & 33,890 & 34,208 & 34,528 & 34,849 & 35,171 & 35,332 & 35,654 \\
\hline & II & 22,764 & 24,455 & 26,123 & 26,470 & 26,822 & 27,173 & 27,514 & 27,677 & 27,995 \\
\hline \multirow{2}{*}{ Uू } & I & 82,075 & 82,409 & 82,057 & 81,936 & 81,803 & 81,66 & 81,507 & 81,426 & 81,261 \\
\hline & II & 64,614 & 66,769 & 66,842 & 66,958 & 67,031 & 67,068 & 67,081 & 67,079 & 67,067 \\
\hline \multirow{2}{*}{ } & I & 38,433 & 38,198 & 38,038 & 37,996 & 37,947 & 37,894 & 37,84 & 37,814 & 37,762 \\
\hline & II & 27,677 & 29,049 & 29,970 & 30,087 & 30,182 & 30,255 & 30,308 & 30,326 & 30,353 \\
\hline \multirow{2}{*}{ 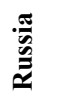 } & I & 146,670 & 143,170 & 140,376 & 139,873 & 139,396 & 138,927 & 138,459 & 138,221 & 137,74 \\
\hline & II & 107,830 & 109,399 & 111,990 & 111,103 & 110,813 & 110,365 & 109,817 & 109,516 & 108,892 \\
\hline \multirow{2}{*}{ 总 } & I & 287,842 & 302,741 & 317,641 & 320,613 & 323,577 & 326,526 & 329,446 & 330,890 & 333,759 \\
\hline & II & 205,439 & 217,913 & 231,001 & 233,731 & 236,502 & 239,279 & 242,017 & 243,349 & 245,972 \\
\hline \multirow{2}{*}{ } & I & 48,870 & 46,936 & 45,433 & 45,167 & 44,909 & 44,657 & 44,409 & 44,287 & 44,044 \\
\hline & II & 36,511 & 36,441 & $\mathbf{3 6 , 3 2 7}$ & 36,223 & 36,084 & 35,912 & 35,712 & 35,600 & 35,363 \\
\hline \multirow{2}{*}{ : } & I & 59,128 & 61,013 & 62,637 & 62,916 & 63,180 & 63,431 & 63,670 & 63,785 & 64,011 \\
\hline & II & 44,066 & 45,862 & 47,397 & 47,665 & 47,896 & 48,124 & 48,343 & 48,450 & 48,662 \\
\hline \multirow{2}{*}{ 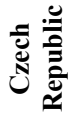 } & I & 10,224 & 10,195 & 10,411 & 10,443 & 10,466 & 10,482 & 10,496 & 10,503 & 10,518 \\
\hline & II & 7,848 & 8,032 & 8,335 & 8,379 & 8,413 & 8,437 & 8,454 & 8,459 & 8,465 \\
\hline
\end{tabular}

freedom occupies the last 44th place among the countries of Europe [4], and its overall ranking is lower than the regional and weighted average world-wide scores. With the government's efforts to introduce a number of democratic reforms that would contribute to 
the development of the state and increase the level of economic freedom, the growth of distrust in the judicial system, the system of public administration and the high level of corruption, greatly complicate and impede the socio-economic development of Ukraine and constitute real threats to improve the economic system of state and welfare improvement [7]. A vivid evidence of this is the assessment of experts of the level in a corruption survey, according to which, for several consecutive years, Ukraine has headed the ranking of the most corrupted countries in the world with an actual $88 \%$ in 2018 , while the average value of this indicator in the international rating is 51\% [8]. This fact is an extremely shameful phenomenon for Ukraine, especially during the war, when it seemed that the whole country should mobilize as much as possible and defend its national, political and economic interests. Nowadays, it is entirely determined that corruption is one of the key inhibitory factors for improving the well-being of citizens.

Simultaneously human resource is the main factor of economic development, so the dynamism of its distribution and localization in the geoeconomic scale entirely depends on the conditions of movement, functioning and potential use, which, first of all, are determined by the skill of state regulation and the peculiarities of the influence and interaction of the components of the fiscal space of the state. Ukraine has a significant potential for the formation of a high-quality human capital, because it is among the top 50 countries in the world in terms of higher education quality and has $44^{\text {th }}$ place in 2018 [9]. Instead, the problem is rising in the demographic situation, every year Ukraine loses 4,057 thousand able people on average due to labor migration, low birth rates, aging of the nation, etc. (Table 3.) [7].

In general, a similar negative trend in the dynamics of the population is observed in states where there is unstable economic situation: Belarus, Russia, Ukraine. In the countries of the European Union, where economic growth is stable but not sufficient, the demographic increase is moderate: (Poland, the Czech Republic) as opposed to powerful economies (Great Britain, Germany, France). In addition, an increase in the number of able

Table 4. Dynamics of indexes of wealth of Ukraine, countries in Europe and the world in 2000 and 2016 [7].

\begin{tabular}{|l|r|r|r|r|r|r|}
\hline \multirow{2}{*}{\multicolumn{1}{|c|}{ Indexes }} & \multicolumn{2}{|c|}{ Ukraine } & \multicolumn{2}{c|}{ Europe } & \multicolumn{2}{c|}{ World } \\
\cline { 2 - 7 } & \multicolumn{1}{c|}{$\mathbf{2 0 0 0}$} & \multicolumn{1}{c|}{$\mathbf{2 0 1 6}$} & \multicolumn{1}{c|}{$\mathbf{2 0 0 0}$} & \multicolumn{1}{c|}{$\mathbf{2 0 1 6}$} & \multicolumn{1}{c|}{$\mathbf{2 0 0 0}$} & \multicolumn{1}{c|}{$\mathbf{2 0 1 6}$} \\
\hline Total wealth, bn USD. & $\mathbf{3 4}$ & $\mathbf{4 4}$ & 33,5 & 73,305 & 116,944 & 255,708 \\
\hline $\begin{array}{l}\text { Wealth per adult, } \\
\text { USD }\end{array}$ & $\mathbf{9 4 1}$ & $\mathbf{1 , 2 5 4}$ & 60,888 & 125,460 & 31,651 & 52,819 \\
\hline $\begin{array}{l}\text { Financial wealth per } \\
\text { adult, USD }\end{array}$ & $\mathbf{2 7 5}$ & $\mathbf{2 7 4}$ & 34,930 & 66,374 & 20,475 & 33,517 \\
\hline $\begin{array}{l}\text { Non-Financial wealth } \\
\text { per adult, USD }\end{array}$ & $\mathbf{6 8 6}$ & $\mathbf{1 , 3 9 6}$ & 35,688 & 81,011 & 16,147 & 27,963 \\
\hline Debt per adult, USD & $\mathbf{2 0}$ & $\mathbf{4 1 7}$ & 9,730 & 21,925 & 4,972 & 8,660 \\
\hline $\begin{array}{l}\text { Median wealth per } \\
\text { adult, USD }\end{array}$ & $\mathbf{2 1 3}$ & $\mathbf{1 3 3}$ & 4,191 & 11,319 & 1,266 & 2,222 \\
\hline
\end{tabular}

people in these states is also fixed due to the refuge support from the Middle East and Central Asia. The contingent of migrants in these countries is quite diverse in terms of their intellectual and professional abilities, whereas in the USA, Canada, where, due to the government's foreseeable policy, aging migration traditions have developed, mostly focused on the accumulation of skilled labor from various social groups.

State policy in the field of regulation of human capital has a direct impact on the distribution of wealth and financial conditions for the formation and functioning of the fiscal space of the state (Table 4.) [7]. 
Table 5. Dynamics of wealth distribution in selected countries of the world in 2000 and 2016.

\begin{tabular}{|c|c|c|c|c|c|}
\hline Indexes & $\begin{array}{l}\text { GDP per } \\
\text { adult, USD }\end{array}$ & $\begin{array}{l}\text { Wealth per } \\
\text { adult, USD }\end{array}$ & $\begin{array}{l}\text { Wealth per } \\
\text { adult, USD }\end{array}$ & $\begin{array}{l}\text { Total } \\
\text { wealth, bn } \\
\text { USD }\end{array}$ & $\begin{array}{l}\text { Share of } \\
\text { wealth, \% }\end{array}$ \\
\hline & 2016 & 2000 & 2016 & 2016 & 2016 \\
\hline Belarus & 9,750 & 2,239 & 1,259 & 9 & 0 \\
\hline $\begin{array}{c}\text { United } \\
\text { Kingdom }\end{array}$ & 58,878 & 162,999 & 288,806 & 14,150 & 5,5 \\
\hline Canada & 70,993 & 108,464 & 270,179 & 7,546 & 3,0 \\
\hline Germany & 56,447 & 89,77 & 185,175 & 12,419 & 4,9 \\
\hline Poland & 20,788 & 8,871 & 24,584 & 746 & 0,3 \\
\hline Russia & 29,945 & 2,935 & 10,344 & 1,126 & 0,4 \\
\hline $\begin{array}{l}\text { United } \\
\text { States }\end{array}$ & 75,992 & 206,116 & 344,692 & 84,784 & 33,2 \\
\hline Ukraine & 6,796 & 941 & 1,254 & 44 & $\mathbf{0}$ \\
\hline France & 61,991 & 103,619 & 244,365 & 11,891 & 4,7 \\
\hline $\begin{array}{c}\text { Czech } \\
\text { Republic }\end{array}$ & 27,370 & 11,775 & 48,357 & 409 & 0,2 \\
\hline
\end{tabular}

At the same time, it should be noted that the distribution of wealth per adult has a clear tendency to increase in divergent economic development countries (Table 5). The main feature of such situation is a variety of factors, first of all, global inflation, in addition, the natural population movement and its special feature to accumulate the most mobile able people to self-improvement in the states with a high level of economic development.

Table 6. Distribution of wealth in Ukraine, Europe and the world in $2016[7]^{* *}$.

\begin{tabular}{|c|c|c|c|c|c|c|c|c|c|}
\hline 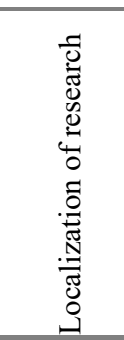 & 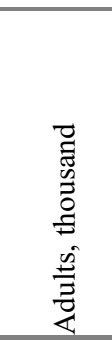 & 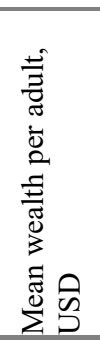 & 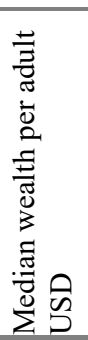 & 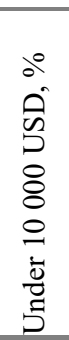 & $\begin{array}{l}\therefore \\
0 \\
0 \\
0 \\
8 \\
8 \\
8 \\
0 \\
1 \\
8 \\
0 \\
0\end{array}$ & $\begin{array}{l}8 \\
8 \\
8 \\
8 \\
1 \\
1 \\
80 \\
8 \\
8 \\
0\end{array}$ & 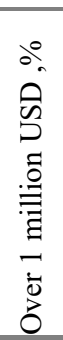 & $\frac{0^{\circ}}{\stackrel{\pi}{0}}$ & 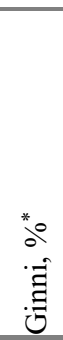 \\
\hline 1 & 2 & 3 & 4 & 5 & 6 & 7 & 8 & 9 & 10 \\
\hline Ukraine & 35363 & 1254 & 133 & 99,1 & 0,8 & 0,1 & 0,0 & 100 & 91,7 \\
\hline Europe & 584293 & 125460 & 11319 & 46,7 & 26,7 & 22,9 & 1,7 & 100 & 84,9 \\
\hline World & 4841193 & 25819 & 2222 & 73,2 & 18,5 & 7,5 & 0,7 & 100 & 92,7 \\
\hline
\end{tabular}

* - the Gini coefficient is a macroeconomic indicator that characterizes the differentiation of money income of the population in the form of the degree of deviation of the factor distribution of income from an absolutely equal distribution among citizens [10].

** - Distribution of adults (\%) by wealth range (USD). 
At the same time, the study of average weights of wealth prevents the possibility of determining the appropriate asymmetries of the financial sector of the fiscal space. According to the international research on welfare determination, Ukraine systematically loses not only the number of inhabitants, in particular the adult population, but the distribution of wealth in the country is depriving the state of a key aspect to restore the stability of its socio-economic development - the presence of the middle class and determine Ukraine to the category of poor countries (Table 6.).

Taking into account interconnection of all the above-mentioned components of the fiscal space, we should outline the prospects for the development of the social direction in Ukraine (Table 7.).

Table 7. Index dynamics of social progress in selected countries of the world in 2017 [11].

\begin{tabular}{|l|c|c|c|c|c|}
\hline \multicolumn{1}{|c|}{ Country } & Total score & Rank & $\begin{array}{c}\text { Basic human } \\
\text { needs }\end{array}$ & $\begin{array}{c}\text { Foundations } \\
\text { of wellbeing }\end{array}$ & Opportunity \\
\hline Belarus & 67,80 & 65 & 87,20 & 67,37 & 48,84 \\
\hline United Kingdom & 88,73 & 12 & 92,96 & 90,28 & 82,96 \\
\hline Canada & 89,84 & 6 & 94,88 & 86,64 & 88,00 \\
\hline Germany & 88,50 & 13 & 94,46 & 89,78 & 81,26 \\
\hline Poland & 79,65 & 32 & 90,69 & 81,48 & 66,80 \\
\hline Russia & 67,17 & 67 & 79,31 & 72,09 & 50,01 \\
\hline United States & 86,43 & 18 & 93,42 & 84,19 & 81,68 \\
\hline Ukraine & $\mathbf{6 8 , 3 5}$ & $\mathbf{5 4}$ & $\mathbf{7 9 , 9 1}$ & $\mathbf{6 8 , 6 2}$ & $\mathbf{5 6 , 5 3}$ \\
\hline France & 85,92 & 19 & 92,49 & 89,16 & 76,10 \\
\hline Czech Republic & 84,22 & 22 & 95,50 & 85,00 & 72,15 \\
\hline
\end{tabular}

Detailing, it should be noted that the highest index of social development set among the following factors: Nutrition and Basic Medical Care 98,47; Access to Basic Knowledge 97,52; Water and Sanitation 89,12; Access to Information and Communications 73,84. At the same time, the lowest points in the study are determined due to the indexes: Tolerance and Inclusion 40,52; Environmental Quality 50,37; Health and Wellness 52,73; Personal Freedom and Choice 53,56; Personal Safety 57,32.

\section{Conclusions}

Thus, taking into account the peculiarities of Ukraine functioning in the competitive conditions of global economic transformations in order to ensure the positive dynamics of macroeconomic indexes, the priority task is to restore peace and establish political stability in the state. At the same time, solving issues related to the formation of fiscal space, capable of generating prospects for the development of the national economy, guaranteeing the security of society and promoting its self-improvement, perhaps in the context of an integrated approach to solve existing problems. One of the first steps in this direction should be the fight against corruption, which is the so-called "Ukrainian brand" in all spheres of public life of the country. From small local officials to government officials there are complex corrupt schemes, a circular guarantee of the Soviet Union, among which the average citizen feels in danger, social tension and poverty.

The total poverty of Ukrainians today little depends on the size of the shadow economy, the impact of economic imbalances, or the formation of oligarchic monopolies on state assets, land and mineral resources. Redistribution of goods is unlikely to become an effective way of fighting poverty, and in today's conditions it is very effective means of manipulating human consciousness in the election race. The problem itself, however, is low labor efficiency, inadequate qualifications of the workforce, obsolete equipment, oriented to 
the production of raw materials with no added value. In such circumstances, professional workers are forced to migrate searching better conditions for using their competencies.

Reforming the Ukrainian economy with the aiding of the oligarch in promoting business development would significantly improve the domestic economic system in the shortest terms. The methods of state support can be varied: from providing tax privileges [Crisis Preferential Taxation] to targeted assistance in a particular industry, type of activity, etc. At the same time, the openness and transparency of fiscal policy, the clear and accessible legislation is strict and objectively defined responsibility for its violation, must become a prerequisite.

Taking into consideration the unusual situation, the state today faces a difficult dilemma that borders on rhetorical Shakespeare's questions: "to be or not to be". Delaying by government with a radical re-launch of state regulation methods, demonstrative imitation of the effectiveness of economic and social reforms, and a hefty struggle for their own independence are direct threats to the loss of not only the competitive advantages of Ukraine in the global economic space, but also the full opportunity of losing its capacity.

\section{References}

1. R. Roy, A. Heuty, E. Letouzé, Fiscal Space for What? Analytical Issues From a Human Development Perspective : paper for the G-20 Workshop on Fiscal PolicyIstanbul, June 30 - July 2, 2007 (2007),

http://www.undp.org/content/dam/aplaws/publication/en/publications/povertyreduction/poverty-website/fiscal-space-for-what/FiscalSpaceforWhat.pdf, 9.08.2018

2. V. Kadygorb, Z. Design, N. Popovych. Ukraina vglobalnyh rejtyngah / Zagalnyj perelik rejtyngiv (2018), https://www.pravda.com.ua/cdn/graphics/ratings/index.html, 3.08.2018

3. Transparency International Ukraine / CPI, https://ti-ukraine.org/en/cpi/ (03.08.2018)

4. 2018 Index of Economic Freedom: Country Rankings (2018), https://www.heritage.org/index/ranking, 3.08.2018

5. Ukraine due to the level of economic freedom 2018 / Index of Economic Freedom / / Economic Discussion Club, http://edclub.com.ua/analityka/ukrayina-za-rivnemekonomichnoyi-svobody-2018

6. O. Kolisnuchenko, Tiniova ekonomika Ukrainy dosiagla 45\% - IMF „Ekonomichna pravda" (2018), https://www.epravda.com.ua/news/2018/02/9/633941, 9.08.2018

7. A. Shorrocks, J. Davies, R. Liuberas, Research Institute: Thought leadership from Credit Suisse Research and the world's foremost experts (2016), http://publications.credit-suisse.com/tasks/render/file/index.cfm?fileid=AD6F2B43B17B-345E-E20A1A254A3E24A5, 3.08.2018

8. Corruption perception by country / EY Fraud Surveys (2018), https://fraudsurveys.ey.com/ey-emeia-fraud-survey-2017/detailed-results/corruptionperception-by-country/, 7.08.2018

9. QS Higher Education System Strength Rankings (2018), https://www.topuniversities.com/system-strength-rankings/2018, 9.08.2018

10. S. Mochernyy [red.], Ekonomichna enklopediya: u trioh tomah (Akademia, Kyiv, 2002)

11. 2017 Social Progress Index (2018), http://www.socialprogressimperative.org/\#data table/countries/spi/dim1,dim2,dim3, $\underline{3.08 .2018}$ 